\title{
NORMAS PARA APRESENTAÇÃO DOS TRABALHOS
}

Os trabalhos submetidos devem:

1) ser inéditos;

2) apresentar título na língua do artigo e em inglês (obrigatoriamente);

3) a primeira lauda deve iniciar com o título em português (ou na língua estrangeira do texto, caso o artigo seja todo escrito em língua estrangeira);

4) o cabeçalho deve ser seguido pelo resumo do artigo, expressando de forma clara a ideia do trabalho. Apresentar um resumo de até 200 palavras, na língua do artigo e em seguida o respectivo resumo em inglês, abstract;

5) o artigo deverá conter até 5.000 palavras;

6) os textos deverão ser digitados com a seguinte configuração: espaço simples, corpo 12, tipo Times News Roman, formato de papel A4, em documento word;

7) os textos em língua portuguesa deverão ser redigidos conforme a norma de apresentação de artigos da Associação Brasileira de Normas Técnicas ABNT - NBR6022, de maio de 2003. Para os artigos em língua estrangeira deverão ser utilizadas as normas: MLA (na área de literatura) e APA (para os artigos de estudos linguísticos). Para artigos que sejam traduzidos da língua estrangeira para a portuguesa, deverão ser utilizadas as normas ABNT;

8) as citações no corpo do texto deverão ser redigidas de acordo com o padrão estilístico correspondente a cada área: artigos em língua estrangeiraLiteratura - (MLA), Linguística (APA) e artigos em português - ABNT. Favor consultar Normas para Citação: NBR10520, para Referência NBR6023, ambas de 2002; 
9) palavras-chave devem vir logo abaixo do resumo em português e também adicionadas em inglês, logo abaixo do abstract. Em ambos os casos, devem ser separadas por ponto final. Sugere-se a utilização de três a cinco termos (no máximo);

10) os textos não deverão ser paginados

Importante: Os textos serão submetidos aos Conselhos Editorial e Consultivo da revista e serão analisados atendendo à periodicidade da publicação. Caberá aos Conselhos decidir sobre a aceitação ou não do trabalho, e fazer sugestões relativas tanto à apresentação quanto às exigências editoriais. Os textos que não estiverem de acordo com as Normas Editoriais serão devolvidos para que sejam feitas as devidas alterações. 